University of Nebraska - Lincoln

DigitalCommons@University of Nebraska - Lincoln

Faculty Publications: Department of Teaching, Department of Teaching, Learning and Teacher Learning and Teacher Education

Education

2008

\title{
Content is Not Enough: A History of Secondary Earth Science Teacher Preparation with Recommendations for Today
}

Elizabeth B. Lewis

University of Nebraska-Lincoln, elewis3@unl.edu

Follow this and additional works at: https://digitalcommons.unl.edu/teachlearnfacpub

Part of the Teacher Education and Professional Development Commons

Lewis, Elizabeth B., "Content is Not Enough: A History of Secondary Earth Science Teacher Preparation with Recommendations for Today" (2008). Faculty Publications: Department of Teaching, Learning and Teacher Education. 118.

https://digitalcommons.unl.edu/teachlearnfacpub/118

This Article is brought to you for free and open access by the Department of Teaching, Learning and Teacher Education at DigitalCommons@University of Nebraska - Lincoln. It has been accepted for inclusion in Faculty Publications: Department of Teaching, Learning and Teacher Education by an authorized administrator of DigitalCommons@University of Nebraska - Lincoln. 


\title{
Content is Not Enough: A History of Secondary Earth Science Teacher Preparation with Recommendations for Today
}

\author{
Elizabeth B. Lewis
}

\begin{abstract}
Division of Curriculum \& Instruction, Mary Lou Fulton College of Education,
\end{abstract} Arizona State University, Tempe, AZ 85287, Elizabeth.B.Lewis@asu.edu

\section{ABSTRACT}

Secondary geoscience education has its roots in geography and physiographic education from the turn of the $20^{\text {th }}$ century. High school Earth science reached a peak during the late 1960s and 1970s, after plate tectonic theory revolutionized geology. The production of Earth science teachers, unlike biology teachers, has never reached full capacity, which has likely contributed to the lesser presence and status of Earth and space science in U.S. high schools today. Historically, the geoscience community has focused on enriching teachers' geoscience content knowledge, but modern Earth and space science teachers need more than just content knowledge.

Based on current science education research, today's Earth and space science teacher education programs should also include: a) science methods that embrace authentic inquiry and state-of-the-art technology and visualization resources, b) an exploration of formative assessment and how to modify instruction to meet students' learning needs, c) awareness of common misconceptions and strategies to affect conceptual change, and d) how to establish scientific classroom discourse communities to promote scientific literacy. However, geoscience education researchers should prioritize investigations of Earth and space science teacher preparation programs as very little is known about the relationship between such programs, teacher implementation, and student learning.

\section{INTRODUCTION}

In the last century the purpose of science education has changed greatly because of various social and political priorities. Those commissioned to study science education and all aspects relating to it, including science teacher preparation, have offered many criticisms and recommendations for reform. From the beginning of the $20^{\text {th }}$ century in the United States there was much criticism of science teachers in general, which focused on teachers' lack of scientific knowledge arising from insufficient scientific study in colleges and universities (National Society for the Study of Education, 1932). As a result, many early recommendations for the preparation of science teachers centered on the depth and breadth of required science content courses as opposed to pedagogical strategies.

While geology is not by any means a new science, it was formalized in American public schools after other sciences and historically has had to fight for equal status among its sister sciences (Dodick and Orion, 2003a). Additionally, research in science education, science teacher education, and professional development is relatively new to educational research (Lieberman, 1992). Unfortunately, geoscience education, and subsequent research, has lagged behind other science domains as it was never considered to be a critical part of the curriculum alongside life and physical sciences until the 1960s. Secondary Earth science education is not even mentioned, with the exception of general reference to the teaching of geography or physiography, in either the $31^{\text {st }}$ (1932) or $46^{\text {th }}$ (1947) Yearbook of the National Society for the Study of Education. Thus, the community faces a compounded challenge that other academic disciplines, and even other sciences, do not.

How to best educate teachers is a perennial debate and the preparation of Earth and space science teachers is no exception. However, in order to critique our past and move effectively forward we require a synthesis of how we have approached the challenge of producing enough high-quality Earth science teachers. There have been very few studies on this matter and volumes that synthesize American science education (Robinson, 1968; Hurd, 1969; DeBoer, 1991; Akin and Black; 2003) lack substantial insights into geoscience teacher education. Through combing the research literature, I have connected historical snapshots to show how the geoscience and education communities have grappled with Earth and space science preservice teacher program design and professional development throughout the $20^{\text {th }}$ century. Concerns about teacher preparation and qualifications have intensified with the advent of the National Science Education Standards (National Science Education Standards) (NRC, 1996), that include inquiry-based science teaching standards, "highly qualified" teacher status through the No Child Left Behind Act of 2001 (NCLB) federal legislation, and the on-going practice of other teachers' assignment to teach Earth and space science out-of-field.

By outlining a chronology of secondary Earth science education in the United States, we can see how Earth science teachers have been prepared to teach an evolving science and continue to struggle to be equal partners in secondary science education. Recommendations for modern Earth and space science teacher education programs are made based on current key research on effective teaching practices, the NSES (NRC, 1996), and the Blueprint for Change: Report from the National Conference on the Revolution in Earth and Space Science Education (Barstow and Geary, 2002). I have endeavored to use consistently the terms "Earth science" and "Earth and space science" in their historical contexts. Until recently the discipline had been referred to as Earth science. However, with the publication of the NSES and reframing of Earth science into Earth systems science, this $\mathrm{K}-12$ domain of science is now referred to as Earth and space science (ESS). This acknowledges the more integrated view of the major interacting systems of the geosphere, hydrosphere, atmosphere, and exosphere (space). Victor Mayer argues in Global Science Literary (2002) that the Earth systems science concept is fundamental to all sciences and "with the proper education in science, such as effective global science literacy programs, [everyday citizens] could become well informed in science and of the knowledge science develops concerning our habitat" (p. xii). 


\section{MODERN EARTH AND SPACE SCIENCE EDUCATION AND TEACHER QUALIFICATIONS}

\section{Status of Earth and Space Science Education} Currently secondary ESS is most commonly taught at the $8^{\text {th }}$ or $9^{\text {th }}$ grade level (Bezanson, $6 / 26 / 07$ ) and only about $7 \%$ of U.S. high school students take ESS as opposed to $88 \%$ who take biology (Barstow and Geary, 2002). The situation is somewhat better at the 8th grade level where ESS is taken as a full year-long course by approximately $20 \%$ of all students. However, most middle school science teachers with a science major are biology majors with introductory courses in other science areas (Bezanson, 6/26/07). Only $19 \%$ of all $8^{\text {th }}$ grade ESS teachers have geoscience majors while $39 \%$ have other science majors, $21 \%$ are elementary certified, and $21 \%$ are not certified (National Education Assessment Program, 2000). Fifteen percent of all high school science teachers are assigned to teach one or more sections of ESS, and of those teachers, $72 \%$ are certified to teach ESS and have a major or a minor concentration in the field (Council of Chief State School Officers, 2003).

The status of high school ESS still maintains a backseat to the so-called "Nobel" sciences (Dodick and Orion, 2003a) that are perceived to require higher mathematics competency. Frequently ESS is offered as a course for those students who are seen as unmotivated and unable to do "real" science, like chemistry and physics. Even when offered, high school ESS is often skipped over by many talented and motivated science students in favor of an accelerated college preparation track to earn advance placement credits. This prevents students' access to a third of their opportunities to achieve scientific literacy, as per the NSES, and negates the vision for a K-12 coordinated program of scientific literacy. Additionally, elementary education provides limited opportunities to learn science in all disciplinary areas. From a cognitive perspective, it is difficult for secondary students to construct conceptual understandings of any science without the support of prior knowledge and a rich K-6 conceptual framework. Many others have addressed the issues of elementary science education and lack of adequate teacher preparation (see an excellent summary by Appleton, 2007), which are too broad to be dealt with here.

I argue that teachers' status is closely aligned with the status of what subject matter, and what level, they teach and that the ill-informed, persistent view that ESS can be taught by any science teacher is evidence of its low status. Accordingly, it is often acceptable in secondary school course assignments to have less qualified science teachers teach "remedial," lesser (e.g., Earth) science courses that don't require the same math fluency as chemistry and physics courses. This is often the case in schools with at-risk students who need science credits to graduate high school. Other authors have written arguments in favor of stronger ESS education in the United States and the reader is directed to read those discourses (AAAS, 1990; NRC, 1996; Mayer, 1995; Mayer, 2002; Barstow and Geary, 2002). While the status of ESS is not the main issue of this article, it is an important contextual factor.

Science Education Policy - Geoscience education advocates have been forced to closely monitor the activities of state-level educational policy-makers to prevent the elimination of state-level K-12 ESS standards. Ironically, ESS standards were removed from state documents, in California, North Carolina, and Texas in the late 1980s and 1990s even though these states benefit greatly from mineral and fossil fuel resources and frequently experience natural disasters. It was only through advocate groups' and individuals' efforts that geoscience grade 9-12 standards were later returned. Such limited acceptance of ESS as valuable and viable can affect the need for a supply of qualified geoscience educators, but in general there are never enough qualified ESS teachers to fill available positions. Consequently, other science teachers must step and teach a subject in which they have little or no education.

The Geological Society of America's (GSA) Education Task Force report in GSA Today, entitled New Directions and Strategies for Excellence (2000) provides the following argument for teacher preparation initiatives and promoting ESS education:

\begin{abstract}
A geoscience education effort directed toward enabling faculty to establish programs to help geology majors obtain teacher certification in conjunction with their geoscience degrees can be shown to provide direct benefits to a much larger sector of societal members. Preparation of competent earth science teachers attracts students, contributes to departmental growth, and develops a cadre of professionals who can further contribute to the mission of the Society. (p.10)
\end{abstract}

While this recommendation is a straightforward statement, its success hinges on the full, enthusiastic cooperation of geoscience faculty and the support and merit they afford students who seek teacher licensure through their departments. Ironically, it seems that recent professional development efforts for geoscience faculty themselves have focused on basic pedagogical strategies to improve their own teaching. How can we expect geology faculty without teacher licensure to model effective instructional practices in geoscience education to future teachers? A more effective approach may be to team science education specialists with geoscience faculty so as to take advantage of both areas of expertise in developing interdisciplinary geoscience teacher preparation programs; thus modeling the value, interdependence, and necessity of both. The body of research on teaching shows that expertise in a content area does not ensure that one is an expert pedagogue (Berliner, 2001). Additionally, because geoscience departments presently grant only about a third of the number of geoscience degrees as in the early 1980s (Ridky, 2002), and some are facing the dismantling of their departments, the time is right to follow the lead of other institutions in conceptualizing a broader use of a geoscience degree. This is especially critical when there is a need for qualified teachers in both secondary and post-secondary intuitions. A program called Linkages, formed by the American Geophysical Union (AGU) and with support from the National Science Foundation is "working to design teacher preparation programs that would link teacher preparation and science content classes" (Ridky, 2002). Recent programs at institutions of higher education, such as Michigan Tech and the University of Maryland have tried to address this need by creating programs that encourage majors to become teachers. 
Teaching Standards - The National Science Education Standards (NRC, 1996) for science teaching have been accepted by such prestigious organizations as the National Board for Professional Teaching Standards (NBPTS) for National Board Certification in science education. The NBPTS, initiated in 1987, was created "to increase the professional development of teachers, the status of the teaching profession, and the quality of education in America" (NBPTS, 1989). The NBPTS offers certification in Adolescence and Young Adulthood Science, with a specialization in Earth and space science, to support its vision of mastery for in-service teachers. This is a significant acknowledgement of the importance of ESS education and of those who would teach it.

Persistence of Out-of-Field Teaching - The acceptance of preparation in any area of science, as sufficient to teach ESS has persisted at the level of state licensure for decades. Today about $50 \%$ of states nationally offer a subject-specific license in Earth science (Barstow and Geary, 2002). These states have enacted rigorous testing and licensure practices, including high expectations for college-level geoscience coursework and subject-specific ESS state teacher exams. However, there is much work left to be done considering the wide variance in how states have adopted, or failed to adopt, the spirit of the NSES (NRC, 1996), Project 2061's Science for All Americans (AAAS, 1990), and Benchmarks for Scientific Literacy (AAAS, 1993). These documents have firmly instated ESS as an equal domain of K-12 science alongside its sister domains of life and physical science (NRC, 1996). These visionary standards for fostering scientific literacy have been in circulation for over 15 years to guide states, curriculum coordinators, administrators, and science department faculty in their development of state and district science standards and curricula. By failing to follow through with such standards we sabotage our chances of educating a scientifically literate citizenry.

Biology, a Model for Overcoming UnderRepresentation? - Ridky (2002) argues that other areas of science don't face the same "challenge of having an adequate, well-trained corps of teachers" (p. 17). Indeed, it is apparent that ESS teachers $(14,057$ in 2000) have never reached a critical mass in the same way as biology teachers $(51,048$ in 2000). At the turn of the 20th century biology was considered a lesser, nearly non-existent, secondary level science (NSSE, 1932), just like Earth science was in the 1950s. However, high school biology has flourished and one rarely hears arguments for students to skip the course or to eliminate biological sciences from the high school curriculum, perhaps with the exception of anti-evolutionists. In considering the big picture, more women $(39,913=62 \%)$ than men $(23,989=$ $38 \%$ ) are majoring each year in the biological sciences while in the geosciences, men $(1,812=57 \%)$ still outnumber women $(1,358=43 \%)(\mathrm{NSF}, 2007)$. Women have steadily increased their proportions as pre-college science teachers since 1977, now roughly $52 \%$. Therefore, it follows that geoscience departments with lower enrollments and fewer women will likely produce fewer new geoscience teachers (Lewis, 2008). This is not to argue that education is solely women's work, but to acknowledge the reality that men are not entering the teaching work force at the same rates as women.

\section{HISTORICAL STUDIES OF EARTH SCIENCE TEACHER PREPARATION}

The literature research question at hand is specific to the history of secondary Earth science teachers' preparation in the United States during the last century and does not include the issue of elementary or college teachers of ESS or geology. Journals that focus on science education, science teaching, and teacher preparation were consulted for Earth science teacher preparation, including: the Journal of Science Teacher Education, Science Education, the Journal of Teacher Education, Teaching and Teacher Education, and the Journal of Research in Science Teaching. Only a few articles were found to concentrate specifically on the Earth science teachers' education. Most studies concern program evaluations of specific Earth science curriculum, professional development initiatives, and program descriptions and recommendations for preservice science teacher preparation in general. Another primary resource was an issue-by-issue review of 56 years of the Journal of Geological Education (later renamed the Journal of Geoscience Education in 1996), spanning from the first volume in 1951 to May 2007. The rationale for a review of this journal, along with Geotimes, published by the American Geological Institute, is that they are major resources and communication outlets for geoscience teachers within the larger geoscience community. For historical information about Earth science education some key works were consulted (Robinson, 1968; Hurd, 1969; DeBoer, 1991; Akin and Black; 2003) as well as all of the few early National Society for the Study of Education (NSSE) annual yearbooks dedicated to science education and teacher preparation (The 31st Yearbook, Part I: $A$ Program for Feaching Science, 1932; The 46th Yearbook, Part I: Science Education in American Schools, 1947).

History of U.S. Earth Science Education and Teacher Preparation - The National Education Association's Committee of Ten met at the end of the 19th century to establish educational norms and resolved that science should occupy at least $25 \%$ of the syllabus. The Committee recommended that physical geography be taught at the $9^{\text {th }}$ grade, biology at the $10^{\text {th }}$ grade, chemistry at the $11^{\text {th }}$ grade, and physics at the $12^{\text {th }}$ grade (NEA, 1894). Influenced by a report by the U.S. Bureau of Education, general science began to displace geography. By the 1950s general science, as an introduction to and preparation for upper level chemistry and physics, occupied a major place in 9th grade in secondary schools (Barstow and Geary, 2002). This is an interesting trend considering that 20 years prior the 1932 NSSE yearbook committee members expressed serious reservation about general science:

Ever since its introduction into the curriculum general science has had to make its way in the face of decided difficulties and handicaps. Thus there is probably no subject in the high-school program which has so frequently been assigned to inadequately prepared or totally unprepared teachers - "anyone can teach general science" has been the conviction of many administrators (p.122-123). 
It seems that tradition and politics kept general science in place and even today many high schools still offer a general science or physical science course over ESS. Perhaps it is not only the status of ESS in general that has lead to its lack of emphasis in schools and poor staffing, but also the position of when it is taught. Teaching less mature $9^{\text {th }}$ grade students is potentially a less desirable assignment among teachers and whatever subject is taught to $9^{\text {th }}$ graders is perceived to be less important and require less expertise than teaching $11^{\text {th }}$ or $12^{\text {th }}$ grade chemistry and physics. Regardless, the NSSE committee stated its "unqualified condemnation" of this situation (NSSE, 1932, p.131). It was their opinion that general science would be better omitted from the science program of studies, especially if it was presented as a reading course and/or taught by an inadequately prepared teacher, even if that teacher is trained in another science area. As stated earlier, teaching out-of-field is an old and resistant problem.

At the turn of the century the Industrial Revolution was in full force and the increase in mechanization and growth of factories spilled over into educational theory and practice. The Cult of Efficiency and the teacher as laborer rather than creative professional was a critical influence on the preparation of teachers and the delivery of curriculum. The linear school of curriculum theory was the dominant model of educational reform where the most material was delivered to the most students in the least amount of time. This is reflected in the NSSE yearbook topics of the time. For example, in 1915 (Part II) the yearbook topic was Methods for Measuring Teachers Efficiency and in 1916 (Part I) Standards and Tests for the Measurement of the Efficiency of Schools and School Systems. Later, in the 31st Yearbook of the NSSE Part I: A Program for Teaching Science (1932), the tone appears to soften and be more intellectual, human, and professional in its expectations for, and attitudes toward, teachers. In the chapter on "Programs for the Education of Science Teachers in State Teachers Colleges" the committee states that "the program of teacher education should be judged from the standpoint of its adequacy for liberal education and from the standpoint of its adequacy for professional education" (NSSE, 1932, p. 325). However, the committee expressed its concerns for "the fact that in current practice in state teachers colleges an adequate attainment of these standards for the education of teachers is not secured or even closely approached" (NSSE, 1932, p. $325)$. This chapter also summarizes the $7-12^{\text {th }}$ grade science educational records of 1,586 students entering teachers colleges in Pennsylvania and neither geology nor Earth science is listed as a course. Additionally, the teaching of Earth science is never mentioned, thus confirming the lack of an organized course at the high school level at this time.

In the $1920 \mathrm{~s}$ and 30 s preservice teachers entering teachers' colleges were often expected to take a general science course, especially for those who were seeking elementary teaching degrees. This general course included some basic Earth science content. Those teachers who sought to teach high school science usually divided their time between more advanced college science courses and required education courses in sociology and psychology (NSSE, 1932). The committee stressed their concern that:

It is impossible to teach any subject well without an adequate background of subject-matter training. Courses in methods and in other phases of education constitute a necessary part of the equipment of the teacher, but these courses should be considered always as additional to those required to provide a necessary background of subject matter; they should never be permitted as substitutes for subject matter. ( $p$. 333)

Clearly, and understandably, subject matter knowledge was deemed to be of primary importance. The NSSE committee commented that the "teachers college cannot escape responsibility for giving this specific professional training" (NSSE, 1932, p. 335). The specific recommendations for teaching high school science included introductory courses in each of the specialized sciences (chemistry, physics, and biology) for 18-24 semester hours of credit, $12-16$ credit hours in the specialized field, and 4 credit hours each in the electives of geology, physiography, astronomy, and bacteriology. Geology classified as an elective reflects its low status of the time. The NSSE committee also states that satisfying this outline of courses would be a minimum for specialization and that they should not only satisfy the criterion of "respectable scholarship," but that science teachers may be in the position of teaching more than one subject and should also have more breadth of knowledge.

Earth science was introduced as a special class for gifted $9^{\text {th }}$ grade students by the New York State Education Department in 1949. New York was one of the first states, along with Pennsylvania, to adopt Earth science as part of the state curriculum, which was adopted by hundreds of schools in those states (Matthews, 1964). In 1957 participants in the International Geophysical Year, "spoke frequently about the need for better earth science instruction in public schools" (Ridky, 2002, p.16). One cannot ignore the American-Soviet Union space race and its effect on prioritizing science education in the United States. By 1965 , as reported at a conference held by the Earth Science Curriculum Project, more than 500,000 secondary students were enrolled in Earth science nationwide (Romey, 1966) often replacing physical geography and general science at the 9th grade. In 1967 the Earth Science Curriculum Project (ESCP) was released and was considered to be a model for inquiry-based instruction. The ESCP set the standard for Earth science education and promoted further enrollment (Barstow and Geary, 2002). Rachel Carson and J. Tuzo Wilson used their influence as part of the ESCP Advisory Board to contribute to the curricular vision of Earth science in schools and with the support of the American Geological Institute (AGI) Earth science grew rapidly in the schools (Ridky, 2002). The (ESCP) was initiated in part to elevate the status of Earth science education and to be comparable to the Biological Sciences Curriculum Study (BSCS) and Physical Science Study Committee (PSSC) physics programs (Heller, 1965). The ESCP leadership made regular reports to the readership of the Journal of Geological Education (JGE) during the 1960s while the AGI made its first significant effort to improve Earth science education nationally. Many articles detailing the progress of Earth science education in various states also appeared regularly in $J G E$ and presented the issues of teacher preparation and licensure, always with the plea for more Earth science teachers in schools. Stephenson (1964) suggested conservatively that by 1970 over 13,000 Earth science 


\begin{tabular}{|c|l|}
\hline Chronology & \multicolumn{1}{|c|}{ Project Description } \\
\hline 1963 - 1966 & $\begin{array}{l}\text { "Time, Space, and Matter" (TSM) - Secondary School Science Project (SSSP) supported } \\
\text { by NSF with associated Teacher Resource Program (terminated in 1971); 8 regional } \\
\text { centers around the country. }\end{array}$ \\
\hline 1967 & $\begin{array}{l}\text { Earth Science Curriculum Project (ESCP) - Geological Society of America, Boulder, } \\
\text { Colorado, and its associated initiative the Earth Science Teacher Preparation Program } \\
\text { (ESTPP) supported by the National Science Foundation. }\end{array}$ \\
\hline $\begin{array}{l}\text { Crustal Evolution Education Project (CEEP) - NAGT and a grant from the NSF; } \\
\text { published by Wards Natural Science Establishment A collection of 33 Earth science } \\
\text { laboratory activities about the phenomenon of plate tectonics and the evidence that } \\
\text { supports the theory. This project had the additional benefit of having been evaluated } \\
\text { by Victor Mayer and his colleagues, while it was being field-tested with a number of } \\
\text { Earth science teachers nationally. The Mayer reports include brief descriptions of } \\
\text { teacher characteristics of those Earth science teachers who participated in the CEEP } \\
\text { professional development initiatives. }\end{array}$ \\
\hline $\begin{array}{l}\text { EarthComm - American Geological Institute. Textbook and curriculum initiative } \\
\text { designed to improve Earth and space science education in schools. The text is packaged } \\
\text { in a modular, thematic format with less reading material than a standard textbook and } \\
\text { more inquiry-based activities. }\end{array}$ \\
\hline 2001
\end{tabular}

Table 1. Major geoscience curriculum reform and associated teacher professional development efforts since 1963.

teachers would be needed. A few years later, Merrill and Shrum (1966) argued that "current evidence suggests that this estimate should be increased, perhaps by several thousand" (p. 23). The ESCP staff in 1966 predicted that there would be a need for 20,000 teachers by 1970; at the time there were only about 6,000 to 7,000 "more or less qualified earth science teachers" (Romey, 1966, p.89). Merrill and Shrum (1966) recognized that there was no hope of meeting this projected need, but recommended strenuously that the geological community try to gain as many new teachers as possible and asserted "the quality of competent teachers in the nation's schools will determine whether or not the next generation understands the import of earth sciences well enough to live intelligently in an age of science" (p.25). Forty years later, at only about 14,000 teachers, we still haven't answered their call.

Ridky (2002), using the student enrollment numbers generated by the U.S. Department of Education's National Center for Education Statistics, argues that the situation in Earth science education appears to have worsened since the 1960s. Since 1962, high school enrollments have increased by $31 \%$ from almost 9 million to about 13 million students. The number of students taking Earth science has only increased by about 100,000, which is roughly a $20 \%$ increase from the 1965 estimation by the ESCP. This translates into about an $11 \%$ decrease in high school enrollments in high school Earth science.

The increase in Earth science education through the 1960 s and 1970s did not continue through the 1980s and in the late 1990s a conceptual physics course (Physics First) was promoted by Leon Lederman (2001) as a more logical grades 9-12 curricular order. The rationale for this initiative was not supported by any educational research data. Lederman's high school curricular design further displaces $9^{\text {th }}$ grade Earth and space science and disregards the vision of the NSES (1996) and goal of scientific literacy as defined by the AAAS Benchmarks (1993). For those interested in a more detailed history, Mayer and Fortner (2002) outline the political influences that have affected a trend to reduction science in American public education. Orion and Ault (2007) also point to a reductionist philosophy of science education having "historically constrained the introduction of earth sciences" (p. 658).

Earth Science Curriculum Initiatives - Throughout the later half of the $20^{\text {th }}$ century there has been on-going criticism of the preparation of Earth science teachers, centered mainly on the science curriculum and content that these teachers should know as educators. Much effort has been expended by the National Association of Geology Teachers, the Geological Society of America, and the American Geological Institute, often with the financial support of the National Science Foundation, to develop curriculum and in-service teacher professional development that reflects the nature of geoscience. Case in point, the most major modern revolution in geology, the discovery of seafloor spreading and the resulting theory of plate tectonics of the $1960 \mathrm{~s}$, drove massive textbook revision, teacher professional development, and of course, new curriculum initiatives (Table 1). This was an exciting time for both geology and geoscience education and it is easy to forget that this major revolution happened just 50 years ago. Despite these initiatives it appears that the lack of first-hand formal education in Earth science has contributed to the difficulty of persuading the general public that ESS is a scientific discipline with equal status with biology, chemistry, and physics. This is notwithstanding the unique quality of geoscience education as a visual and accessible science. Many contributors to JGE have made arguments for local place-based geoscience education as a means for engaging students and teachers even in urban settings (Riggs and Kimbrough, 2002; Semken, 2005; Riggs, Robbins, and Darner, 2007). The critical need for geoscience education is greater than ever with issues of global warming, increases in the occurrence of severe tropical storms and coastal flooding, and depletion of natural resources such as fresh water and fossil fuels.

During the 1970s and 1980s, following the major paradigm shift in understanding how the earth's geosphere functions as a part of other Earth systems, the Crustal Evolution Education Project (CEEP) by the 
National Association of Geology Teachers came into development and use. CEEP provided activities using real data from the sea floor and modeling such concepts as isostasy and density in the context of Earth's crustal dynamics, activities that are still used today. The project is an excellent example of collaboration between scientists and educators and helped to further the importance of using real-world data for learning. This tradition continues today by collaboration between TERC and the long-established and highly-regarded Earth science textbook authors Spaulding and Namowitz (2001) with their on-line, interactive, data-based geoscience activities (www.classzone.com). What we need to know more about is how teachers are using such resources in their classrooms.

Historical Earth Science Teacher Preparation Preparing Tennessee Teachers - There are very few historical studies available from which to piece together exactly how Earth science teachers have been prepared during the early and middle 20th century. A rare report found in the Journal of the Tennessee Academy of Science describes a state-wide perspective on Earth science teacher preparation (Rice and Corgan, 1974). This historical case study reveals that Earth science was a rapidly expanding teaching field in Tennessee secondary schools and that two new certification programs were to be enacted in February 1974. Apparently almost half of Tennessee's four-year post-secondary institutions could graduate students who met broad-field certification requirements (Rice and Corgan, 1974). In February 1973 the Tennessee State Board of Education approved both endorsements for Earth science teachers. Rice and Corgan (1974) comment that this was the first "clear and official statement of the minimum professional background required for competence in the classroom" (p.11). They also report that by 1971, 141 of 147 public school systems had indicated that they had plans to adopt an Earth science text, an enormous increase over just nine school systems only two years previously.

A major project (supported by NSF) called the Earth Science Teacher Preparation Program (ESTPP) was concurrent with the expansion of Earth science in Tennessee high schools. Corgan himself was one of eleven faculty members from colleges and universities who acted as an advisor to the ESTPP and ran an experimental program at Austin Peay State University in Tennessee. During 1971-72 Rice and Corgan reviewed certification requirements from 20 states and studied national guidelines. The final requirements for certification of Earth science teachers in Tennessee in 1973 were a total of 24 quarter credit hours, of which there were 9 geology, 3 physical geography, 3 astronomy, 3 weather or meteorology, and 6 others from two or more of the following: soils science, oceanography, conservation of natural resources, or cartography (Rice and Corgan, 1974). The broad-field endorsement required "a minimum of 48 quarter hours of credit in the sciences (biological science, chemistry, physics, and earth and space science) with at least three areas represented...earth and space science included physical geography, geology, astronomy, meteorology, and oceanography" (Rice and Corgan, 1974, p.13).

Rice and Corgan (1974) also report the results of a survey on: a) the number and variety of Earth science courses offered during the 1972-73 academic year, b) information on the existence of formal major and minor programs in Earth science, and c) data on the administrative locus of Earth science offerings. The survey was sent to all post-secondary Tennessee institutions that offered teacher preparation programs in science and were accredited by the Southern Association of Colleges and Schools. A major concern was whether or not a potential teacher would be able to become certified at these institutions. The results indicated that larger institutions offered a wider array of science courses and the possibility of certification in Earth science.

National Studies - A series of studies reported in Science Education in the 1970 s by Mayer $(1972,1976)$ yields limited information about the required science content of Earth science teacher preparation from a national sample of colleges that offered such a degree. Only in the third study (Mayer, 1976) were there any survey questions about the teaching methods courses and the degree of cooperation between the science departments and the colleges of education, and this information is quite general. Mayer does offer us an empirically-derived average Earth science teacher preparation program from the period between 1964 and 1974, which included:

1) Courses in the earth sciences (26 semester hours) required: astronomy ( $3 \mathrm{hr}$ ); physical geology $(4 \mathrm{hr})$; historical geology $(4 \mathrm{hr})$; mineralogy ( $3 \mathrm{hr})$; paleontology $(3 \mathrm{hr})$; geomorphology $(3 \mathrm{hr})$; meteorology (3 hr); oceanography ( $3 \mathrm{hr}$ ).

2) Supporting sciences (17 semester hours) required: biology $(5 \mathrm{hr})$; chemistry $(6 \mathrm{hr})$; physics $(6 \mathrm{hr})$.

The only major changes from this average program, as calculated from the 1964-65 survey, are the addition of an oceanography course and the deletion of a physical geography course (Mayer, 1976). Mayer (1976) comments that between 1969 and 1974 one area of requirements that changed significantly was the development and requirement of Earth science teaching methods courses, which he stated was encouraging. Annual enrollments for 1973-74 appeared to be relatively low, with the number of graduating Earth science teachers ranging from zero in two programs and 22 in one (mean $=6$ teachers, $S D=6.36$ ) (Mayer, 1976). These figures were a cause for concern and Mayer points out it is especially concerning that during those times of relative prosperity (the late 1960s) the numbers of graduating Earth science teachers remained as low as they did.

A more recent survey by Harris (1995) notes that traditionally most Earth science teacher preparation and enhancement programs have been situated in geology or geoscience departments. Unfortunately, most have experienced significant decreases in their enrollments since the early $1980 \mathrm{~s}$. Consequently, these declining enrollments have likely affected the last 25 years' supply of Earth science teachers. This supports Ridky's 2002 statements as to a severe shortage of geoscience majors to feed into ESS teacher ranks. With a shortage of in-service ESS teachers there also comes a shortage of capable mentor teachers for student teaching placements to sustain teacher growth.

Science Teacher Preparation - From the literature that was reviewed, the historical arguments and concerns for preparing Earth science teachers appear to center mainly around the distribution of college-level geoscience coursework. There is very little mention of what the 
content of the methods and other professional courses in education teachers should have in their programs of study. Some position papers from the late 1960 s and early 1970 s began to outline, in general terms, other areas that should be included in the preparation of science teachers. Yager (1993) reports that in 1965 Newton and Watson concluded what was likely the first major study of science teacher education. In the early 1990s many colleges and schools of education suffered severe cuts in staff and funding. Yager (1993) comments that the underlying message was that coursework in schools of education didn't contribute to becoming a good teacher; in fact it was widely thought that teachers were likely to be better if they had less time in education classes. The idea that content knowledge alone was sufficient to be a competent teacher has been difficult to overcome. Many institutions had science teacher education, but only employed one professor of science education. Numerous small institutions didn't have a science educator with a Ph.D., and/or teaching experience in a K-12 setting, and these institutions prepared a third of all newly certified science teachers each year (Brockway, 1989).

Returning to the 1965 study, published in 1968 , by Newton and Watson, Yager (1993) summarizes their conclusions about science teacher preparation programs:

1. There are examples of every conceivable pattern somewhere in the U.S., whether referring to methods courses, student teaching arrangements, course requirements, or program sequences.

2. There is almost a complete lack of objective evidence on effectiveness of programs, though students are demanding information concerning the effectiveness of their programs.

3. Science educators involved in teacher education in the U.S. appear to be isolated from their counterparts at other institutions.

4. There are neither agreed-upon goals nor structures for science teacher education in the U.S. (p.144).

Two other studies followed in 1980 (Yager) and 1985 (Iskandar) funded by NSF. As of 1993 Yager reported that nationally there were 1,250 institutions with science teacher preparation programs. He recommended that four factors should be considered to encourage real reform in science teacher education: a) defining leadership, b) forming partnerships, c) using what we know, and d) building collaboratives (p.145). Yager also comments that "the business model for leadership has no place in education" (p.145). Many would wholeheartedly agree and extend the criticism of this view as an inappropriate and cold attitude toward educating children. The business model is merely a white-collar name substitution for the factory model of 100 years ago. It promotes the attitude that rather than valued and trusted professionals, teachers are disposable and easily-replaced, as were the factory laborers of the past and the office worker of today.

Yager (1993) cites the work of Miller and Driver who identified failures from science classrooms and programs. "Cognitive scientists have found that $85-90 \%$ of physics undergraduates and engineering majors can not apply what they seem to know ... we fail with even the most interested and gifted $85 \%-90 \%$ of the time" (Yager, 1993, p.146). Consequently, Yager proposes that constructivist teaching, the perspective of curriculum as a vehicle rather than a goal, and teacher assessment practices and abilities be the focus for improvement of science teaching and learning.

Reflection - Perhaps it should not be surprising that the field of geoscience education has always lagged behind other science disciplines. This is most likely due to the relatively few geoscience majors that have historically been produced over time and the smaller percentage of those who dedicate themselves to ESS education. Those who become knowledgeable enough about social and cognitive science research methods to research the field of geoscience education and teachers themselves are even fewer and farther between. The message seems clear enough: without increasing undergraduate enrollments and generating enthusiasm for careers in education, the geoscience community faces permanent second-class status.

While the cognitive approach to learning ESS has become more sophisticated, Yager's points are well taken that curriculum is only a vehicle to improving science education. There are a number of persistent educational issues that the geoscience community faces. These issues include: a) the continued use of under-qualified ESS teachers, due to the supply deficit, reinforced by the persistence of a wide range of state requirements for ficensure; b) underrepresented groups' historically limited access to geoscience education and careers including geoscience teaching; and c) lack of coordination between science and education faculty in the training of new science teachers. To address these concerns we must move beyond the historical science content criteria debate. Certainly possessing well-developed geoscience content knowledge is a minimum qualification for ESS teachers, but content alone is insufficient to be an effective teacher.

\section{THE FUTURE OF EARTH AND SPACE SCIENCE TEACHER PREPARATION}

So, what should Earth science teachers know? What could be considered sufficient conceptual and pedagogical frameworks from which to teach ESS? How can colleges and universities best prepare new ESS teachers for the modern classroom and the world that they share with their students?

In synthesizing criteria for modern teacher preparation programs the NSES (1996), AAAS (1993), and Barstow and Geary (2002) documents were consulted. Additionally science teacher education, teacher knowledge, and preparation literature (Anderson and Mitchener, 1994; Borko and Putnam, 1996; Wilson and Berne, 1999) was referenced. The critical role of educational assessment (NRC, 2001), in particular formative assessment (Bell, 2000; Black and Wiliam, 2002), and other educational researchers' findings on the value of scientific classroom discourse communities (Yerrick and Roth, 2005) round out the recommendations for modern secondary ESS teachers' preparation.

Issues of equity, the status of girls and women and other underrepresented groups, are an important part of teachers' knowledge and these issues have been addressed by numerous authors, most recently in a recent special volume of the JGE (December 2007). However, it was clear that through this literature review that equity has been voiced more frequently since the women's and civil rights movements of the 1960 s and 1970s. Many fine articles have appeared over time in 
both the JGE and Geotimes with appeals to their memberships for leveling the playing field for the benefit of both the individual and geoscience professions.

National Standards and ESS Reform Documents The NSES include K-12 content standards, standards for inquiry, teaching standards, and science program standards. The vision of the NSES clearly state that "student understanding is actively constructed through individual and social processes" (p.29) and the "actions of teachers are deeply influenced by their understanding of and relationships with students" (p.29). The NSES teaching standards reflect the shift to a more inquiry-based curriculum with more emphasis on:

1) understanding and responding to individual students' interests, strengths, experiences, and needs; 2) selecting and adapting curriculum; 3 ) focusing on student understanding and use of scientific knowledge, ideas, and inquiry processes; 4) guiding students in active and extended scientific inquiry; 5) providing opportunities for scientific discussion and debate among students; 6) continuously assessing student understanding; 7) sharing responsibility for learning with students; 8) supporting a classroom community with cooperation, shared responsibility and respect. (p.52, emphasis mine)

Clearly, these are all vital qualities we wish to promote in all of our science teachers, but in preparing ESS teachers, university geoscience faculty responsible for training new teachers should be deliberate in integrating these elements into their science methods courses.

Participants at the National Conference on the Revolution in Earth and Space Science Education (NCRESSE) (Barstow and Geary, 2002) recommended that "close attention should be paid to Earth as a system as the central paradigm, science as inquiry as a dominant approach to teaching and learning, and integration of computer-based analysis tools, Internet and visualization technology into the curriculum" (p.29). Additionally, the conference report includes the recommendation that states support teacher certification in ESS and on-going professional development. In brief, the five top recommendations are that new and veteran teachers should strive to: a) gain an extensive knowledge of ESS, b) understand effective pedagogical content strategies related to ESS, c) know how to use web-based technology and other technological tools and resources, d) be life-long learners, and e) teach in alignment to state science standards (p.56).

The NCRESSE document also addresses teacher assessment practices: "Provide opportunities for practicing and preservice teachers to learn how to assess student learning effectively and identify student misconceptions" (p. 53). Finally, in terms of improving equity and diversity in geoscience education the document advocates for recruiting potential ESS teachers from underrepresented groups and supporting them through bridge projects from high school to college graduation. These are important goals, and I would add that in order to achieve such aims geoscience department faculty also need to bridge the gap between the culture of Western modern science and the everyday culture of all students and the cultural values and norms of underrepresented groups (Cobern and Aikenhead, 1998; Lewis, 2008).

Earth and Space Science Content: How Much is Enough? - How much college-level geoscience content is enough to provide a secondary teacher with a conceptual framework of the science and a sense of the nature of geoscience? If any aspect of Earth science teacher preparation has been repeatedly dissected by the geoscience education community, it has been the role of Earth science content knowledge. Without a doubt content knowledge is a minimum requirement and there is a whole body of research devoted to subject matter preparation. Obviously, "a teacher's own knowledge of a subject will enhance or limit the opportunities a student has to learn that subject" (Anderson and Mitchener, 1994, p.14). From a research perspective there is a need for empirically determining the balance between ESS content and teaching knowledge as has been systematically pursued in the field of teacher preparation in mathematics education (Ball, Lubienski, and Mewborn, 2001). Once this balance is determined, there would be a data-driven argument for specific requirements for ESS teacher licensure to authoritatively discourage out-of-field teaching assignments.

Inquiry-Based Science Instruction - Teachers may erroneously believe that if they are doing hands-on activities with their students that they are by default implementing inquiry-based instruction in their classrooms. Teaching inquiry-based science requires an awareness of learning cycles, such as the 5E's (Engage, Explore, Explain, Elaborate, and Evaluate, from the BSCS research and the earlier Karplus learning cycle models), and a willingness to let go of lecture and teacher-driven triadic dialogue or "initiate-respond-evaluate" (IRE) questioning structure (Gallego, Cole, and The Laboratory of Comparative Human Cognition, 2001; Lemke, 1990). Also, teachers who are unskilled at formative assessment (as part of "Evaluate") and erroneously think that students have acquired more than a rote understanding of science, may be unwilling to change their practices because they think what they are doing is working. ESS is a rich ground for inquiry-based learning and educators should capitalize upon students' questions about the world around them to engage their minds and reveal their ideas.

ESS Pedagogical Content Knowledge - As defined by Carter (1990), pedagogical content knowledge "involves both what teachers know about their subject matter and how that knowledge is translated into classroom curricular events" (in Munby, Russell, and Martin, 2001, p.880). Shulman and Sykes (1986) define PCK as "domain specific and includes a teacher's knowledge of students' interest and motivation to learn particular topics within a discipline and understandings about students' preconceptions that can interrupt or derail their learning" (in Munby, Russell, and Martin, 2001, p.880).

Teachers have been indoctrinated to schools first as students (the so-called "apprenticeship of observation") and spend many years forming beliefs about how science is taught and about how they themselves learn science best. The dominant classroom structure that has been employed for many decades is the recitation script (Galleo, et al., 2001), in which the teacher stands at the front of the room and presents information for students to copy into their notes. Teachers have traditionally 
conducted classroom discussions most frequently by using IRE where the teacher initiates a question to check for student understanding, receives a response, and evaluates it (Lemke, 1990). This instructional strategy severely limits the degree to which students can actively engage with concepts and each other as part of a scientific classroom discourse community (Yerrick and Roth, 2005). It is not surprising that new teachers rely heavily on this way of teaching as they are often concerned about their classroom management and lecturing gives them a feeling of greater control. Also, while novices "may focus on surface features or particular objects, experts draw on a store of knowledge that is organized around interpretive concepts or prepositions that are tied to the teaching environment" (Munby, Russell, and Martin, 2001, p. 889). To limit students' opportunities for peer-to-peer discourse and the construction of scientific explanations by relying mainly on lecture and whole group discussion also fails to meet the NSES (1996) inquiry standards.

Research on science teaching suggests that teaching experience makes a significant difference in how teachers' knowledge becomes interconnected (Munby, Russell, and Martin, 2001). Berliner (2001) discusses expertise in terms of being specific to a domain and is a non-linear phenomenon that develops over hundreds and thousands of hours, and importantly that "expert knowledge is structured better for use in performances than is novice knowledge" (p. 463). As with the medical profession, clearly there is no replacement for experience and case knowledge gained through careful observation of student learning and reflection about how one teaches.

Understanding of the Nature of Science - An additional complication of teaching ESS may be that teachers' concept of how science is conducted varies from discipline to discipline; e.g., chemistry, which relies more upon controlled experiments than do geologic studies that are more observational and descriptive in nature. Teachers' general concept of the nature of science also may be a significant limiting factor in how they present classroom opportunities for learning science. For instance, if teachers have a positivist view of science (e.g., science is about absolutes, rather than a socio-cultural perspective of science as a human endeavor and semiotic activity) they may choose more traditional, teacher-centered structures as evidenced by lecturing (Lemke, 1990; Lederman, 2007). Additionally, a study of the history, philosophy, and nature of science may assist teachers in constructing a more complex understanding nature of science (Bentley and Garrison, 1991; Lederman, 2007).

Specifically, beginning ESS teachers should be familiar with the history of paradigm changes in the geosciences to better appreciate our changing understanding of geologic phenomena and of the field as a whole. For example, the hegemonic attachment to uniformitarianism at the turn of the 20thth century excluded large-scale catastrophic events to explain geologic phenomena. This was seen in the arguments about the geologic history of the Channeled Scablands of Washington State, and the difficulty that J. Harland Bretts had in 1927 convincing the geologic community that a massive flood had shaped these phenomenal geomorphic features. By knowing the history of science teachers better appreciate the tentative nature of scientific claims and can convey this to their students.
Those activities that allow for students to discuss scientific data and frame claims supported by evidence are more reflective of a teacher who understands how the scientific community works in a social context. However, this also returns to the issue of PCK in that in order to select a focus for student discourse "the teacher needs sophisticated knowledge of the discipline - the way the discipline is put together, what simple things are fundamental" (Leinhardt, 2001, p. 346).

Knowledge of Assessment - The role of assessment in teaching and learning cannot be underestimated, in particular the use of formative assessment; "there is strong and rigorous evidence that improving formative assessment can raise standards of students' performance" (Black and Wiliam, 2004). Bell (2000) provides a useful review of the relevant literature in formative assessment in the context of science education and she outlines the key phases of eliciting, interpreting, and acting on information to improve student learning. ESS teachers should be given opportunities to improve their knowledge and skills using small-scale, on-the-spot, quick assessments that allow them to understand what students understand and don't understand. For example, the use of concept maps or a KWL graphic organizer (i.e., What do I know? What do I want to know? What did I learn?) before starting a lesson on the geologic time can quickly give the teacher a sense for what aspects of the concept need the most attention. However, formative assessment is not formative if teachers fail to adjust their lesson plans to accommodate students' learning needs (Black and Wiliam, 2004).

Scientific Classroom Discourse Communities - The cutting-edge model for teaching and learning in science is one that involves the development of scientific classroom discourse communities (Yerrick and Roth, 2005). This is based in socio-cultural leaning theory in the tradition of Vygotsky (1967). Socio-cultural models include communities of practice that are interactive, with situated learning contexts with other people and their environment, with an emphasis on the local construction of meaning (Wenger, 1998). The importance of talking and writing as vehicles to learning scientific academic language as a means to building scientific literacy cannot be underestimated. Teachers are essential to bridging the gap between everyday and scientific discourse, but they need to be taught how to do this effectively.

\section{CONCLUSIONS}

For those institutions that provide geoscience teacher education a failure to engage teachers' beliefs about teaching science, to build disciplinary-specific understanding of the nature of science, and to expand their domain- and topic-specific, as well as general, PCK has serious ramifications for students' experiences in the classroom. Failure in the classroom is ultimately failure in scientific literacy and educational reform. Beginning Earth and space science teachers should be well-versed with common geoscience misconceptions as informed by the growing educational research in the conceptual change literature (Ault, 1982; Dodick and Orion, 2003b; Orion and Ault, 2007). The capacity to use formative assessment is paramount in teaching and learning to show teachers what their students understand and how to adjust their instruction. A working knowledge of human cognition, especially the role of 
socially-constructed knowledge, gives teachers a broader and more informed view of student learning that can potentially avert naïve assumptions and ineffective teaching strategies.

While there was a burst of enthusiasm for Earth science education through the 1960s and 1970s, the numbers of trained ESS teachers have remained far lower than their biology counterparts. Unfortunately, this has resulted in fewer advocates for geoscience education than other science disciplines, little to no recent growth of ESS programs in secondary schools, and declining undergraduate geoscience enrollments. Without a sustained and coordinated effort to improve teacher education, such as that enacted by the Geological Society of America, the NSF, and the support of college and university geoscience departmental faculty with the ESCP in the 1960s, the current situation of American citizens who lack global literacy is unlikely to change.

\section{ACKNOWLEDGEMENTS}

Thanks to Dr. Dale Baker and Ms. Kaatje Kraft for their thoughtful feedback on this manuscript as well as helpful reviewer comments from Drs. Robert Butler and Audrey Rule. My appreciation to Drs. Douglas Clark Steven Semken, Daniel Battey, Michael Piburn, and Finbarr Sloane as well for their enthusiastic encouragement to publish this research. Lastly, I am grateful to my own teachers and colleagues who have modeled great teaching and generously shared their experiences, wisdom, and caring for students.

\section{REFERENCES}

Akin, J.M., and Black, P., 2003, Inside science education reform: A history of curricular and policy change, New York, Teachers College Press.

American Association for the Advancement of Science, 1993, Benchmarks for Scientific Literacy, New York, Oxford University Press.

American Association for the Advancement of Science, 1990, Science for All Americans, New York, Oxford University Press.

American Geological Institute, 2001, EarthComm, Armonk, NY, It's About Time.

Anderson, R.D. and Mitchener, C.P., 1994, Research on Science Teacher Education, In D.L. Gabel (Ed.), Handbook of Research on Science Teaching and Learning, New York, Simon and Schuster MacMillan.

Appleton, K., 2007, Elementary Science Teaching, In S.K. Abell and N.G. Lederman (Eds.), Handbook of Research on Science Education, Mahwah, New Jersey, Lawrence Erlbaum Associates, Publishers.

Ault, C.R., 1982, Time in Geological Explanations as Perceived by Elementary-School Students, Journal of Geological Education, v. 30, p.304-309.

Barstow, D., and Geary, E. (Eds.), 2002, Blueprint for Change: Report from the National Conference on the Revolution in Earth and Space Science Education, Cambridge, MA, TERC (Website: www.Earth ScienceEdRevolution.org).

Ball, D.L., Lubienski, S.T., and Mewborn, D.S., 2001, Research on Teaching Mathematics: The Unresolved Problem of Teachers' Mathematical Knowledge, In Richardson, V. (Ed.), Handbook of Research on Teaching. Washington, D.C, American Educational Research Association.
Bell, B., 2000, Formative Assessment and Science Education, Hingham, MA, USA, Kluwer Academic Publishers.

Bentley, M.L., and Garrison, J.W., 1991, The Role of Philosophy of Science in Science Teacher Education, Journal of Science Teacher Education, v. 2, p. 67-71.

Benzanson, C., 2007, Where are we now? Is there a problem with K-12 Earth Science? http:// serc.carleton.edu/teacherprep/issues/current.html

Berliner, D.C., 2001, Learning about and learning from expert teachers.,International Journal of Educational Research, v. 35, p. 463-482.

Black, P. and Wiliam, D., 2004, The Formative Purpose: Assessment Must First Promote Learning, In M. Wilson (Ed.), Toward Coherence Between Classroom Assessment and accountability, 103rd Yearbook of the National Society for the Study of Education, Part II, Chicago, IL, University of Chicago Press.

Borko, H., and Putnam, R.T., 1996, Learning to Teach, In D.C. Berliner and R.C. Calfee (Eds.), Handbook of Educational Psychology, New York, MacMillian.

Brockway, C., 1989, The status of science teacher education in Iowa, 1988, Unpublished doctoral dissertation, University of Iowa, Iowa City.

Carter, K., 1990, Teachers' knowledge and learning to teach, In W.R. Houston (Ed.), Handbook of Research on Teacher Education, New York, Macmillan.

Cobern, W.W., and Aikenhead, G.S., 1998, Cultural Aspects of Learning Science, In Fraser, B.J. and Tobin, K.G. (Eds.), International Handbook of Science Education, p. 39-52.

Council of Chief State School Officers, Blank, R., and Langesen, D., 2003, State Indicators of Science and Mathematics Education 2003.

DeBoer, G.E., 1991, A History of Ideas in Science Education: Implications for Practice, New York, Teachers College Press.

Dodick, J., and Orion, N., 2003a, Geology as an Historical Science: Its Perception within Science and the Educational System, Science and Education, v. 12, p. 197-211.

Dodick, J., and Orion, N., 2003b, Cognitive Factors Affecting Student Understanding of Geologic Time, Journal of Research in Science Teaching, v. 40, p. 415-442.

Gallago, M.A., Cole, M., and the Laboratory of Comparative Human Cognition, 2001, Classroom Cultures and Cultures in the Classroom, In Richardson, V. (Ed.), Handbook of Research on Teaching, p. 951-997.

Geological Society of America, Education Task Force to GSA Council and Management, 2000, GSA Education: New Directions and Strategies for Excellence, GSA Today, v. 10, p. 10-11.

Harris, W.M., 1995, U.S. Earth Science Teacher Preparation Programs: Status and Directions, Geological Society of America Annual Meeting 1995 Abstracts with Programs, New Orleans, LA, Nov. 6-9, 1995.

Heller, R.L., 1965, The Secondary School Earth Science Course in Science Education, Journal of Geological Education, v. 13, p. 71-74.

Hurd, P.D., 1969, New Directions in Teaching Secondary School Science, Chicago, Rand McNally and Company.

Lederman, L.G., 2007, Nature of Science: Past, Present, and Future, In S.K.Abell and N.G.Lederman (Eds.), 
Handbook of Research on Science Education, Mahwah, New Jersey, Lawrence Erlbaum Associates, Publishers.

Lederman, N., 2001, Revolutionizing Science Education. Physics Today, http://www.physicstoday.org/ vol-54/iss-9/p11.html, retrieved 3/26/08.

Lemke, J.L., 1990, Talking Science: Language, Learning, and Values, Norwood, NJ, Ablex Publishing.

Lewis, E.B., 2008, How to Rebuild Geoscience Departments and Fuel the Revolution in Earth and Space Science Education, Geological Society of America, Cordilleran and Rocky Mountain Sections Annual Meeting 2008 Abstracts with Programs, Las Vegas, NV, March 19-21, 2008.

Leinhardt, G., 2001, Instructional Explanations: A Commonplace for Teaching and Location for Contrast, In Richardson, V. (Ed.), Handbook of Research on Teaching. Washington, D.C: American Educational Research Association.

Lieberman, A., 1992,. Introduction: The Changing Context of Education, In A. Lieberman (Ed.) The Changing Contexts of Teaching, 91st Yearbook of the National for the Study of Education (Part I), Chicago: The University of Chicago Press.

Matthews, W.H., 1964, Current Status of Earth Science in Secondary Schools, Journal of Geological Education, v. 12, p. $60-63$.

Mayer, V.f., 1995, Using the Earth system for integrating the science curriculum, Science Education, v. 79, p. 375-391.

Mayer, V.J. (Ed.), 2002, Global Science Literacy, Dordrecht, the Netherlands, Kluwer Academic Publications.

Mayer, V.J., and Fortner, R.W., 2002, A case history of science and science education policies, In Mayer, V.J. (Ed.) Global Science Literacy, Dordrecht, the Netherlands, Kluwer Academic Publications.

Mayer, V.J., 1976, Requirements in Earth Science Teacher Preparation Programs: 1965 to 1974, Science Education, v. 60, p. $223-234$.

Mayer, V.J., 1972, Changes in Science Requirements in Earth Science Teacher Preparation Programs, Science Education, v. 56, p. 453-458.

Merrill, W.M., and Shrum, J.W., 1966, Planning for Earth Science Teacher Preparation, Journal of Geological Education, v. 14, p. 23-25.

Munby, H., Russell, T., and Martin, A.K., 2001, Teachers' Knowledge and How It Develops, In Richardson, V. (Ed.), Handbook of Research on Teaching, Washington, D.C, American Educational Research Association.

National Assessment of Educational Progress, 2000, U.S. Department of Education, Washington, DC. (Website: http://nces.ed.gov)

National Board for Professional Teaching Standards, 1989 Toward high and rigorous standards for the teaching profession, Detroit: NBPTS.

National Educational Association, 1894, Report of the Committee of Ten on Secondary School Studies with the Reports of the Conferences Arranged by Committee, New York, American Book Company.

National Research Council, 2001, Knowing what students know: The science and design of educational assessment, Committee on the Foundations of Assessment, Pelligrino, J., Chudowsky, N., and Glaser, N. (Eds.), Washington, DC, National Academy Press.
National Research Council, 1996, National Science Education Standards, Washington, DC: National Academy of Science.

National Science Foundation, Division of Science Resources Statistics, 2007, Women, Minorities, and Persons with Disabilities in Science and Engineering. Arlington, VA: NSF. Available at http:/ / www.nsf.gov/statistics/wmpd.

National Society for the Study of Education, 1932, The 31st Yearbook of the National Society for the Study of Education: (Part I) A Program for Teaching Science, Chicago, The University of Chicago Press.

National Society for the Study of Education, 1947, The 46th Yearbook of National Society for the Study of Education: (Part I) Science Education in American Schools, Chicago, The University of Chicago Press.

Orion, N., and Ault, C.R., 2007, Learning Earth Sciences. In S.K. Abell and N.G. Lederman (Eds.), Handbook of Research on Science Education, Mahwah, New Jersey, Lawrence Erlbaum Associates, Publishers.

Rice, R.J., and Corgan, J.X., 1974, Earth Science Teacher Preparation: A State-Wide Perspective, Journal of the Tennessee Academy of Science, v. 49, p. 10-14.

Ridky, R., 2002, Why We Need a Corp of Earth Science Educators, Geotimes, v. 47, p. 16-19.

Riggs, E.M., Robbins, E., and Darner, R., 2007, Sharing the Land: Attracting Native American Students to the Geosciences, Journal of Geoscience Education, $v$. 55 , p. 478-485.

Riggs, E.M., and Kimbrough, D.L., 2002, Implementation of Constructivist Pedagogy in a Geoscience Course Designed for Pre-Service K-6 Teachers, Journal of Geoscience Education, v. 50, p. 49-55.

Robinson, J.T., 1968, The Nature of Science and Science Teaching, Belmont, CA, Wadsworth Publishing Company, Inc.

Romey, W.D., 1966, A Strategy for Alleviating the Shortage of Earth Science Teachers, Journal of Geological Education, v. 14, p. 89-90.

Semken, S., 2005, Sense of Place and Place-Based Introductory Geoscience Teaching for American Indian and Alaska Native Undergraduates, Journal of Geoscience Education, v. 53, p. 149-157.

Spaulding, N., and Namowitz, S., 2001, Earth Science, Upper Saddle River, NJ, Prentice-Hall.

Stevenson, R.C., 1964, Earth science teacher training problems, ESCP Newsletter, NL-2, p. 6-8.

Vygotsky, L., 1986, Thought and Language, Cambridge, Massachusetts, MIT Press.

Wenger, E., 1998, Communities of Practice: Learning, Meaning, and Identity, New York, Cambridge University Press.

Wilson, S.M., and Berne, J., 1999, Teacher Learning and the Acquisition of Professional Knowledge: An Examination of Research on Contemporary Professional Development, Review of Research in Education, v. 24, p. 173-209.

Yager, R.E., 1993, The Need for Reform in Science Teacher Education, Journal of Science Teacher Education, v. 4, p. 144-148.

Yerrick, R.K., and Roth, W.-M. (Eds.), 2005, Establishing Scientific Classroom Discourse Communities: Multiple Voices of Teaching and Learning Research, New Jersey, Lawrence Erlbaum Associates, Publishers. 